\title{
THE SCOPE OF VOLUNTEER ACTIVITY AND PUBLIC SERVICE
}

\author{
ELEANOR BROWN*
}

INTRODUCTION

The idea of public life in America is premised on individual initiative. Democracy demands that citizens give public voice to their views; a market economy demands that people earn their keep. When they are not satisfied with the results of such large and largely impersonal institutions, Americans volunteer. In 1996, the most recent year in which a presidential election was held, 54.2 percent of the adult population voted; 63.2 percent worked; and 48.8 percent volunteered. ${ }^{1}$ Although the proportion of the population volunteering in 1996 fell short of the proportion voting, the amount of time donated loomed large in contrast to the time it takes to vote: Volunteers gave an average of 4.2 hours of their time every week. ${ }^{2}$ Delivering meals to shut-ins, raising money for the PTA, coaching Little League-in myriad ways, volunteers weave important pieces of the social fabric.

This article provides an overview of the scope of volunteering in the United States. It begins with the question "What is a volunteer?" and, with issues of definition and measurement in mind, surveys the available estimates of the size of the volunteer workforce. It then considers the purposes to which this labor is put. Turning from volunteer work to its workforce, it examines some determinants of volunteering, paying particular attention to factors shaping the volunteer activities of the young and the old.

Copyright (C) 2000 by Eleanor Brown

This article is also available at http://www.law.duke.edu/journals/62Brown.

* Professor of Economics, Pomona College.

This article was prepared for the Amateurs in Public Service conference held at Duke University, Nov. 12, 1999. I would like to thank the participants in that conference, with special thanks to Emmett Carson and Charles Clotfelter, for helpful comments, and the John Randolph Haynes and Dora Haynes Foundation for financial support for this research.

1. See U.S. Bureau OF THE Census, Statistical AbStract of THE United States 288, 391, 397 (1997); Virginia A. HodgKINSON \& MURRAY S. WEITZMAN, GIVING AND VOLUNTEERING IN THE U.S.: FINDINGS FROM A NATIONAL SURVEY 2 (1996). In this article, data from HodGKINSON \& WEITZMAN will be identified as referring to the year 1996 even though the twelve-month period in which data was collected extends back into 1995 .

2. See HodgKinson \& WeITZMAn, supra note 1 , at 3. 


\section{A. What Is a Volunteer?}

Scholars have striven to be precise in their usage of the word volunteer. One particularly thoughtful definition defines a volunteer as

an individual engaging in behavior that is not bio-socially determined (e.g., eating, sleeping), nor economically necessitated (e.g., paid work, housework, home repair), nor sociopolitically compelled (e.g., paying one's taxes, clothing oneself before appearing in public), but rather that is essentially (primarily) motivated by the expectation of psychic benefits of some kind as a result of activities that have a market value greater than any remuneration received for such activities. ${ }^{3}$

In short, volunteering is purposeful activity that is not compelled and the productive value of which is not captured by the volunteer.

One might quibble with the notion that volunteering needs to result in something that has market value, in contrast to activities that were intended to have market value but went awry, or ones that pursued goals not related to market value such as lobbying on behalf of unpopular causes. Generally, though, this definition is an apt one for the purposes at hand. It encompasses informal volunteering-good deeds done directly, such as shopping for a frail neighbor or babysitting for a harried one, unmediated by any formal organization, such as a church or a school, through which larger-scale volunteer efforts are coordinated. Such good deeds are not compelled, and they yield value that is not materially returned to the volunteer. The definition also extends to stipended volunteers. As the word "stipend" implies, programs such as AmeriCorps offer modest pay to doers of good works, on the theory that society needs full-time volunteers and that it is hard for very many people to give so much time freely and continue to keep body and soul together. As long as stipended volunteers are employed in "activities that have a market value greater than any remuneration received," they are volunteers as defined above.

The boundaries to volunteering drawn by this definition are by no means universally employed, even among scholars. Ram Cnaan, Femida Handy, and Margaret Wadsworth survey this and other definitions of volunteering used in legal and academic sources, and identify four dimensions addressed by all of them: (1) the voluntary nature of the act; (2) the nature of the reward, whether entirely psychic or simply sufficiently unremunerative for the act to remain largely donative in nature; (3) the auspices under which the work is performed, either orchestrated by an organization or not necessarily so; and (4) the beneficiaries of the act and their relationship to the actor, be they strangers or simply removed from the family circle. ${ }^{4}$ As one reviews data on volunteering, this taxonomy will provide a helpful checklist in keeping track of differences in definitions and how they shape the data that, in turn, shape one's view of the volunteer landscape.

3. David Horton Smith, Altruism, Volunteers, and Volunteerism, in VOLUNTEERISM IN THE EIGHTIES 23, 25 (John D. Harman ed., 1982).

4. See Ram A. Cnaan et al., Defining Who Is a Volunteer: Conceptual and Empirical Considerations, 25 NONPROFIT \& VOLUNTARY SECTOR Q. 364, 369-70 (Sept. 1996). 
The data on volunteers come largely from household surveys; therefore, to the extent interviewers do not propose definitions of volunteering as nuanced as that set out above, any interpretation of household data is aided by a sense of what volunteering means to the general public. To get a sense of the public's understanding of the concept of "volunteer," Cnaan et al. construct twenty-one examples of persons engaged in acts that contain elements of volunteering. ${ }^{5}$ They asked a sample of 514 persons to rank, on a scale from one ("definitely a volunteer") to five ("not a volunteer"), how firmly each scenario fits their notion of volunteering. 6 The example respondents ranked highest is the only one that is "pure" on all four dimensions, describing someone who freely chooses to work unpaid through an organization to benefit a stranger: "An adult who offers his or her time to be a Big Brother or Big Sister." Respondents ranked a high school student giving a presentation on leadership at a religious conference as more purely a volunteer than one working for a nonprofit to add a line to a résumé. ${ }^{8}$ In turn, the résumé builder is ranked above the student compelled by a graduation requirement to do community service.

B. Volunteering in the United States

In May 1989, the Current Population Survey ("CPS") of the U.S. Bureau of Labor Statistics included supplementary questions about volunteering done in the preceding twelve months. ${ }^{10}$ The CPS reaches roughly 60,000 households, gathering information on more than 150,000 individuals in those households. ${ }^{11}$ The results of this large-scale survey suggest that about twenty percent of Americans volunteer in a given year. ${ }^{12}$

In contrast to the CPS estimates, a series of smaller surveys conducted by the Gallup Organization for Independent Sector ("IS") finds much higher rates of volunteering. The CPS estimate of thirty-eight million volunteers in 1988-89 is bracketed chronologically by IS estimates of eighty million adult volunteers, or forty-five percent of the adult population in 1987-88, and ninety-eight million adult volunteers, or fifty-four percent of all adults in 1989-90. ${ }^{13}$ Although the IS survey covers fewer than two percent as many individuals as the CPS does, ${ }^{14}$ there are reasons to suspect the IS estimates are more representative of volunteering among adults.

5. See id. at 375 .

6. See id.

7. See id. at 376.

8. See id.

9. See id.

10. See Howard V. Hayghe, Volunteers in the U.S.: Who Donates the Time?, MonTHLy LAB. REV., Feb. 1991, at 17, 17.

11. See id. at 23 n.1.

12. See id. at 17.

13. See Hodgkinson \& WeItZMAn, supra note 1, at 1-30.

14. See id. at 1; see Hayghe, supra note 10, at 23 n.1. 
First, the IS questions are posed in ways likely to elicit more extensive recall of volunteer activity. The CPS allowed for responses by proxy, and about half of the volunteering data was collected from persons other than the person to whom the data refer. Such proxies "were significantly less likely to report volunteer activity than respondents representing only themselves," ${ }^{15}$ which suggests that proxies were not always aware of the volunteer activities of the persons they represented. ${ }^{16}$

Second, the IS data cover age groups and employ definitions of volunteering that differ from those used by the CPS. The IS data include informal volunteering, while the CPS excludes it and the IS survey covers persons ages eighteen and up, in contrast to the CPS, which covers persons ages sixteen and up. ${ }^{17}$ These differences can be expected to yield a higher count of volunteers in the IS data as IS draws a broader definition of volunteering and excludes an age group in which rates of volunteering were, in the 1980s, typically low.

Based on data from the 1996 IS survey, just under half, 48.8 percent, of the adult population volunteered at some time during the twelve months preceding its spring survey in $1996 .^{18}$ Volunteers donated an average of 4.2 hours per week, for a total of 20.3 billion hours in $1996 .{ }^{19}$ Of this total, 15.7 billion hours fall into a narrower definition of volunteering mediated by organizations, referred to as "formal volunteering." 20 Using average rates of compensation in the non-farm economy, this formal volunteering had a labor-market value of more than $\$ 200$ billion dollars. ${ }^{21}$ Because the IS questionnaire defined volunteering in part as "actually working in some way to help others for no monetary pay," 22 and therefore did not capture stipended volunteering, these figures underestimate the number of hours worked by volunteers, as defined by Smith. ${ }^{23}$

\section{Utilizing Volunteer Labor}

Volunteers are used throughout the economy, from the arts to youth development to supporting churches, synagogues, and other religious communities. As shown in Table 1, IS data classify volunteer assignments according to fifteen categories-fourteen specific categories, plus one catch-all. With two exceptions, volunteer assignments are classified by their area of endeavor, using the following categories: the arts, education, environment, health, human services, international or foreign concerns, political organizations and campaigns, private and community foundations, public and societal benefit, adult recreation, religious organizations, and youth development. The other categories describe

15. Hayghe, supra note 10 , at 19.

16. See id.

17. See id. at 23; see HodgKinson \& WeitzMAn, supra note 13, at 1-2.

18. See HodgKinson \& WeITZMAn, supra note 1 , at 3.

19. See id.

20. $I d$.

21. See id.

22. Id. at E-192 app. E.

23 See supra note 3. 
the organizational framework within which volunteers operate: informal volunteering, whatever the nature of the service provided, and giving time to workrelated organizations, whatever their missions might be.

TABLE 1

VolunteEr Time ACRoss ACTIVITY AREAs, 1996 IS SURVEY

\begin{tabular}{lc}
\hline Area of Activity & $\begin{array}{c}\text { Percentage of } \\
\text { Volunteer Hours }\end{array}$ \\
\hline Religious organizations & $24.5 \%$ \\
Informal & 22.1 \\
Youth development & 15.4 \\
Education/instruction & 14.3 \\
Human services & 10.6 \\
Health, incl. mental health & 10.4 \\
Arts, culture, and humanities & 5.4 \\
Work-related & 4.3 \\
Public/society benefit & 3.6 \\
Recreation (adults) & 3.0 \\
Political & 3.0 \\
Environment/animals & 1.8 \\
Other & 1.7 \\
Private and community foundations & 1.3 \\
International/foreign & 0.6 \\
& Total*: \\
\hline
\end{tabular}

Source: These data are based on the author's own calculations using the 1996 Giving and Volunteering survey data.

* Total does not sum to 100 due to rounding.

The number of activities volunteers take on and the numbers of hours they devote to volunteering vary widely, but the typical volunteer works for a single organization. Sixty-two percent of the volunteers in the 1996 IS survey report volunteer involvement with one organization only. ${ }^{24}$ Twenty-eight percent of volunteers report multiple sites of involvement; the remaining ten percent of the sample failed to answer the question. ${ }^{25}$ These multiple-assignment volunteers are active enough to raise the average number of activities per volunteer to about three. ${ }^{26}$ There is similar dispersion in the number of hours volun-

24. See HodgKinson \& WeItZMAn, supra note 1, at 1-34.

25. See id.

26. See id. at 1-30. 
teered-one in five volunteers devoted less than an hour a week to volunteering, while one in four gave five hours or more weekly. ${ }^{27}$ These variations suggest at least three ways to measure the economy's apportionment of volunteers across different areas of activity: the proportion of the total volunteer labor force involved in each area, the proportion of all volunteer assignments to be found in each, and the proportionate distribution of hours of volunteer time.

In all three measures, religious organizations are the biggest recipients of volunteer services. More than half of all volunteers, 52.9 percent, report at least one religion-based volunteer activity. ${ }^{28}$ More than a quarter, 25.8 percent, of all volunteer assignments are religion-based. ${ }^{29}$ Religion also represents one quarter, 24.5 percent, of the total number of hours of formal volunteering. ${ }^{30}$

The second and third areas, behind religion, are youth development programs, which garner 15.4 percent of volunteer hours, and education, representing 14.3 percent of volunteer time..$^{31}$ The two other areas that claim at least ten percent of the total number of hours spent on formal volunteering are health and human services. These five biggest areas are the ones that deal with "church, children, and charity" and together, they account for three quarters of volunteer time.

Throughout those areas of activity, volunteers serve as a low-cost delivery mechanism for social services. Since the 1980s, there has been a call for private initiative to replace some portion of government initiative in the provision of social services, with emphasis on the roles to be played by nonprofit organizations and volunteers. Much has been written about the stresses placed on the nonprofit sector by shifts in federal expenditures. ${ }^{32}$ Even as it cut funding to areas of nonprofit activity, the federal government has sought to increase the supply of volunteers to select social causes through a panoply of federally supported programs. Part II discusses some of those programs.

\section{II}

\section{PUblic SERVICE: VolunteERS IN THE PUbliC SECTOR AND STIPENDED VOLUNTEERS}

Volunteering, being largely unremunerative, is generally less than a fulltime commitment, and volunteers typically have other and larger commitments in their lives. These circumstances render volunteering an essentially local phenomenon, not something for which volunteers generally relocate. Therefore,

27. These conclusions are based on the author's own calculations using the 1996 Giving and Volunteering survey data.

28. See id. at 1-31.

29. See id.

30. These conclusions are based on the author's own calculations using the 1996 Giving and Volunteering survey data. ries.

31. This data does not include informal giving because informal giving spans all the activity catego-

32. For a recent review, see Lester M. Salamon, The Nonprofit Sector at a Crossroads: The Case of America, 10 Voluntas 5 (1999). 
when the federal government needs full-time volunteers willing to relocate to project sites to serve the public interest, it must in general compensate them. When the duties are clearly public-spirited and the pay minimal, Americans nonetheless tend to accept these activities as volunteering: It is common parlance, for example, to speak of "Peace Corps volunteers."

Local governments, by virtue of being local, usually do not have to buy their volunteers, in part, because they provide attractive volunteer opportunities. Jeffrey Brudney points out that clarity of mission is important to volunteers, and most local government agencies have very clearly defined responsibilities. ${ }^{33}$ A 1985 survey of 736 towns and cities found that 72.6 percent of them used volunteers. $^{34}$ Of these, roughly half had only modest programs, often centered on police auxiliaries and fire fighting. ${ }^{35}$ More than one in five communities using volunteers, however, used them extensively enough to have someone appointed as a volunteer coordinator, and about one in eight used volunteers in at least half a dozen capacities. ${ }^{36}$ A 1993 survey of county governments, conducted by the National Association of Counties, estimated that in 1992, county governments utilized volunteer services with a market value of $\$ 1.8$ billion. ${ }^{37}$ Of the 417 counties responding to the survey, ninety-three percent used volunteers, with more than half using them to support firefighting and emergency medical services, services for the aging, and parks and recreation. ${ }^{38}$

At the federal level, the National and Community Service Trust Act of 1993 established AmeriCorps, folding into it the existing Volunteers in Service to America ("VISTA") and National Civilian Community Corps. ${ }^{39}$ In the same year, the Corporation for National Service ("CNS") was created as an umbrella agency to oversee AmeriCorps, Learn and Serve America, and the National Senior Service Corps, which includes the Retired and Senior Volunteer Program ("RSVP"), the Foster Grandparent Program, and the Senior Companions Program. $^{40}$ In fiscal year 2000, the service programs administered under the CNS had combined budgets of more than $\$ 731.6$ million. ${ }^{41}$

Since its inception, AmeriCorps has placed more than 100,000 stipended volunteers into programs across the country. ${ }^{42}$ Local initiatives apply for

33. See Jeffrey L. Brudney, The Availability of Volunteers: Implications for Local Governments, 21 ADMIN. \& SOC'Y 413, 421 (1990).

34. See Sydney Duncombe, Volunteers in City Government: Advantages, Disadvantages and Uses, 1985 NAT'L CIVIC REV. AT 356, 359.

35. See id. at 364.

36. See id. at 363-64.

37. See Sandra Reinsel Markwood, Volunteers in Local Government: Partners in Service, PUB. MgMT, Apr. 1994, at 6, 7.

38. See id.

39. See 42 U.S.C. $\$ 12501$ (1994).

40. See Corporation for National Service, About Us: Legislative History (visited May 11, 2000) $<$ http://www.nationalservice.org/about/leg_history $>$.

41. See id. at 2.

42. See Corporation for National Service, History of National Service (visited Apr. 22, 2000) $<$ http://www.cns.gov/research/history.html>. 
AmeriCorps support, and projects are chosen through a competitive process. AmeriCorps volunteers have one- and two-year commitments to full-time volunteering. They are paid a stipend- $\$ 7,945$ was the standard annual amount in 1996 - and, if they lack health insurance, are given health coverage worth about $\$ 1,200$. $^{43}$ Volunteers are also given a scholarship $-\$ 4,725$ in $1996^{44}$-for each completed year of AmeriCorps service, up to a maximum of two. The CNS also provides funds to local organizations to help cover various costs associated with their utilization of AmeriCorps volunteers, such as transportation and supervision. Estimates of the costs of the AmeriCorps program per volunteer range from $\$ 18,800^{45}$ to $\$ 31,000 .^{46}$

AmeriCorps volunteers provide a wide array of services, from helping Habitat for Humanity build homes to cleaning beaches to teaching children to read. The goals of AmeriCorps and the other national service programs are to "help solve the nation's unmet education, public safety, environmental and other human needs," to make communities "stronger through service," to improve through their experiences the lives of those who serve, and to instill "a common expectation and experience of" service among Americans "as an integral part of civic responsibility." 47

Early program evaluations of three AmeriCorps projects calculated benefitcost ratios of 1.54 to 2.60 , numbers that have been touted as indicative of the success of the program in addressing social needs in a cost-effective manner. ${ }^{48}$ It is not clear, however, that these numbers are terribly helpful in assessing AmeriCorps's effectiveness as a service-delivery strategy. In particular, much of the calculated excess of benefits over costs comes from high estimated returns to AmeriCorps tuition vouchers. Subsidizing education for persons similar to AmeriCorps volunteers through education awards, under the assumption that the subsidies are necessary and sufficient for the volunteers to continue their education and so increase their lifetime earnings, can yield a high benefitcost ratio. This result justifies programs that encourage people to go to school, but says nothing about the effectiveness of AmeriCorps volunteers in helping others. Including wages paid to participants as "participant benefits" as well as costs, and counting the shortfall between stipends and market wages as a psychic benefit received by the volunteer, are debatable accounting techniques that, like the education award, focus cost-benefit numbers on the volunteers' outcomes rather than on service delivery. In short, these studies do not provide

\footnotetext{
43. See Harris Wofford \& Steven Waldman, AmeriCorps the Beautiful?, POL'Y REV., Sept.-Oct. 1996, at $28,30$.

44. See id. at 30 .

45. See id.

46. See James L. Perry et al., Inside a Swiss Army Knife: An Assessment of AmeriCorps, 9 J. PUB. ADMIN. RES. \& THEORY 225, 242 (1999).

47. Corporation for National Service, supra note 42, tbl.1.

48. See U.S. General ACCOUnting OfFICE, RePOrt HEHS-95-255R, AMERICORPS*USA BENEFIT-COST STUDY 2 (1995).
} 
definitive information about the effectiveness of social service provision through AmeriCorps volunteers.

However effective AmeriCorps may be, its labor force is small in comparison to the efforts of unpaid volunteers. In comparison to roughly 100,000 volunteers having served in AmeriCorps, the 15.7 billion hours volunteered annually by American adults are the equivalent of about eight million full-time workers. ${ }^{49}$

\section{A. Adult Volunteers}

Some basic demographic data on volunteering among adults is presented in Table 2. Volunteering is highest among adults who are white, married, well educated, middle-aged, employed, and from households with above-average incomes.

Economists predict that a high opportunity cost of time depresses volunteering, as do high search costs in matching volunteers to appropriate activities. These competing tendencies influence the volunteer behavior of busy adults. On the one hand, the busier people are, the harder it is to find time for any one thing, including volunteering. On the other hand, the busier they are, the more they come in contact with opportunities to volunteer. In general, the second influence trumps the first, but access to resources, be they time, money, or the human capital accumulated through education, also matters.

With the caveat that one must be careful about attributing causality when observing correlations, these principles can be seen in the 1996 IS survey of adults. Work and children make people busy, and yet both are associated with greater rates of volunteering. People who are retired or not employed are less likely to volunteer than people who are working. Women who work only parttime and people who work for themselves are more likely to volunteer than people whose schedules must accommodate working full-time for someone else. $^{50}$

As shown in Table 2, people with children at home are more likely to volunteer than people with no children at home. Although the IS data do not distinguish between school-age and preschool-age children, the CPS data suggest that parents coping with preschool-age children are less likely to volunteer than parents whose children at home are all ages six years and up. ${ }^{51}$

\footnotetext{
49. See HodgKInSON \& WeItZMAn, supra note 1, at 2 .

50. These conclusions are based on the author's own calculations using the 1996 Giving and Volunteering survey data.

51. See Hayghe, supra note 10, at 18.
} 
TABLE 2

Demographic CHARACTERISTICS OF Adult VolunteERs, By SEX, 1996

\begin{tabular}{|c|c|c|c|}
\hline \multirow[b]{2}{*}{ Characteristic } & \multicolumn{3}{|c|}{ Percent Volunteering in Past Twelve Months } \\
\hline & total & male & female \\
\hline Overall & 48.8 & 45.1 & 52.2 \\
\hline \multicolumn{4}{|l|}{ Education: } \\
\hline High school or less & 35.6 & 30.4 & 40.1 \\
\hline Trade school/some college & 54.5 & 51.2 & 57.5 \\
\hline College graduate & 70.7 & 67.0 & 74.7 \\
\hline \multicolumn{4}{|l|}{ Age: } \\
\hline 18-34 years & 46.1 & 43.0 & 49.3 \\
\hline 35-54 years & 55.1 & 51.5 & 58.6 \\
\hline 55 years and older & 43.5 & 37.7 & 47.9 \\
\hline \multicolumn{4}{|l|}{ Marital Status: } \\
\hline Married & 55.8 & 51.5 & 60.2 \\
\hline Single & 39.5 & 40.4 & 38.6 \\
\hline Divorced/separated & 44.6 & 31.3 & 45.2 \\
\hline \multicolumn{4}{|l|}{ Number of children at home: } \\
\hline None under age 18 & 45.1 & n.a. & n.a. \\
\hline At least one under age 18 & 53.7 & n.a. & n.a. \\
\hline \multicolumn{4}{|l|}{ Employment Status: } \\
\hline Employed & 50.8 & 48.0 & 56.2 \\
\hline Not employed & 44.4 & 35.1 & 47.0 \\
\hline Retired & 40.1 & 33.2 & 46.1 \\
\hline \multicolumn{4}{|l|}{ Annual Household Income: } \\
\hline Under $\$ 20,000$ & 34.5 & 32.9 & 35.5 \\
\hline$\$ 20,000-\$ 39,999$ & 45.6 & 41.0 & 50.2 \\
\hline$\$ 40,000$ and up & 60.6 & 54.9 & 67.0 \\
\hline \multicolumn{4}{|l|}{ Minority Status: } \\
\hline White & 51.9 & 47.3 & 56.1 \\
\hline Non-white & 36.4 & 36.1 & 36.6 \\
\hline \multicolumn{4}{|l|}{ Region: } \\
\hline East & 46.0 & n.a. & n.a. \\
\hline Midwest & 59.6 & n.a. & n.a. \\
\hline South & 39.0 & n.a. & n.a. \\
\hline West & 54.7 & n.a. & n.a. \\
\hline \multicolumn{4}{|l|}{ Religious Affiliation: } \\
\hline Catholic & 49.1 & 45.0 & 52.7 \\
\hline Protestant & 48.8 & 46.5 & 50.7 \\
\hline
\end{tabular}

Source: See Virginia A. HODGKINSON \& MURRAY S. WeItZMAn, Giving AND VOLUNTEERING IN THE U.S.: FINDINGS FROM A NATIONAL SURVEY D147-162, app. D tbls.1-3 (1996). 
Access to resources helps to increase the likelihood that a person volunteers. The relationship between educational attainment and rates of volunteering is particularly striking. People who pursue education beyond high school volunteer much more than those who do not; college graduates are far more likely to volunteer than high school graduates who do not complete a college degree. Volunteer rates also rise with income. Differences across ethnic groups are correlated with differences in average incomes and educational opportunities and, most simply, in the likelihood of having been asked to volunteer..$^{52}$

Among other predictors of adult volunteering, both attitudes and behaviors matter. $^{53}$ People are more likely to volunteer if they think they can make a difference. Among people who agree with the statement "It is in my power to do things that improve the welfare of others," fifty-eight percent volunteered, in contrast to thirty-three percent of persons who disagreed. ${ }^{54}$ Beyond feeling capable of accomplishing something, individuals need to want to accomplish something, if they are to be motivated to volunteer. Among survey respondents who reported that "helping individuals meet their material needs" was a potential "major motivation" to action, sixty-two percent volunteered, far more than the thirty-five percent volunteering among those who reported it to provide "no motivation." 55 For those finding a major motivation in "enhancing the moral basis of society," the volunteer rate was sixty-four percent; for respondents who found this to provide no motivation, the volunteer rate was thirty-two percent. ${ }^{56}$

Behaviors also correlate with volunteering. Having volunteered as a youth dramatically increases the likelihood that a person volunteers as an adult, from thirty-one percent to sixty-five percent. ${ }^{57}$ Regular attendance at a church, synagogue, or other place of worship has a similar effect on volunteer rates; among persons who do not attend services regularly, the volunteer rate is thirty-one percent, much lower than the sixty-four percent rate among persons who attend services nearly every week. ${ }^{58}$ Membership in secular organizations, such as service clubs, fraternities, veterans' groups, bowling leagues, and book clubs, is as strong a discriminator between volunteers and non-volunteers as membership in a religious congregation. Among persons belonging to no secular organization, the percentage volunteering was thirty-two, much lower than the seventy-three percent among persons with some membership affiliation. ${ }^{59}$

Finally, there is a distinct lifecycle profile to the propensity to volunteer. Adult volunteering peaks in the age range thirty-five to fifty-five years, when

52. These conclusions are based on the author's own calculations using the 1996 Giving and Volunteering survey data.

53. See discussion infra Table 3 and related discussion.

54. HodgKinson \& WeITZMAN, supra note 1, at 4-100.

55. Id. at $4-118$.

56. Id.

57. See. id. at 4-88, tbl.4.1.

58. See id. at 4-91, tbl.4.2

59. See id. at 4-94, tbl.4.5. 
people have become established in their careers, their personal relationships, and their communities. ${ }^{60}$ Each side of the lifecycle offers its own interesting questions about engaging citizens in volunteering. Do young persons' experiences with volunteering or mandated community service change their lifetime paths of volunteering? Will increasing levels of health and educational attainment among older Americans increase their rates of volunteering? These questions are addressed in turn.

\section{B. Youth Volunteering}

Data on adult volunteers show clearly that persons who volunteered while young are far more likely to volunteer as adults than persons who did not volunteer as youths. ${ }^{61}$ Much of the interest in youth volunteering has focused not so much on what youth volunteers can accomplish in their communities as on how youth are drawn into volunteering, and how volunteer experiences during youth affect civic awareness and future volunteering.

Although one out of five teens-and one out of every three teen volunteers-began volunteering before the age of twelve, ${ }^{62}$ two recent large-scale studies of youth volunteering have focused on children ages twelve and up. In 1996, IS surveyed a representative sample of 1,007 teens aged twelve through seventeen. ${ }^{63}$ Also in that year, the National Center for Education Statistics within the U.S. Department of Education conducted the 1996 National Household Education Survey ("NHES"). ${ }^{64}$ The survey's final sample included 7,940 students enrolled in grades six through twelve. ${ }^{65}$ The IS survey asked questions about volunteering; the NHES asked about community service.

Both surveys find that teen volunteering or community service, either voluntary or required by schools, is widespread. The IS survey results suggest that fifty-nine percent of teens aged twelve through seventeen volunteered at some time during the past year, with boys and girls roughly equally likely to volunteer. $^{66}$ The NHES was conducted from January through April and asked whether students had volunteered during the school year to date; within this shorter timeframe, an estimated forty-nine percent of students participated in community service. ${ }^{67}$ Compared with the IS estimate that 48.8 percent of the

60. See infra Table 3 and related discussion.

61. See infra Table 3.

62. See Hodgkinson \& Weitzman, Volunteering and Giving Among TeEnagers 12 to

17 YeARs of AGE: FINDINGS FROM A NATIONAL SURVEY 2-25, tbl.2.2 (1996).

63. See id. at 1.

64. See Mary Jo Nolin et al., National Center for EduCATion Statistics, U.S. DeP'T OF

EDUC., NCES 97-331, STUDENT PARTICIPATION IN COMMUNITY SERVICE ACTIVITY 1 (1997).

65. See id. at 30.

66. See HodgKInSON \& WeItZMAn, supra note 62, at 1.

67. See NOLIN ET AL., supra note 64, at 4. 
adult population had volunteered during a twelve-month period, ${ }^{68}$ both of these surveys suggest that school-age teenagers volunteer at higher rates than adults. ${ }^{69}$

Although a larger proportion of teens than adults reports some volunteering within the past year, many teenagers' experiences are quite limited. Teens have many "one-shot" options for volunteering, such as a one-day program to pick up trash in a public park or beach, or a trip to sing in a nursing home or to serve food at a soup kitchen. In the NHES survey, about half of the participants who had performed some community service reported they had done so only on one or two occasions. ${ }^{70}$ At the other end of the spectrum, seven percent of the NHES sample had devoted between thirty-one and eighty hours to community service during the school year to date; and five percent had given more than eighty hours of their time. ${ }^{71}$

The IS data yield higher estimates of the extent of volunteer engagement among teens. Only nineteen percent of their sample gave less than one hour per week. ${ }^{72}$ Six percent reported a weekly average of three to five hours, and thirteen percent reported more than five hours a week. ${ }^{73}$ Among teens who volunteered, the average weekly hours given is $3.5 .^{74}$ Projecting their data to the national level and valuing teen volunteer time at the then-prevailing minimum wage of $\$ 4.25$ per hour, the IS data suggest that teens provided 2.4 billion hours of formal and informal volunteering, and the value to organizations of the formal volunteering was $\$ 7.7$ billion dollars in 1995 . $^{75}$

Should teens be encouraged to volunteer? Exposure to community service is touted for its educational value: Through community service, students experience a mode of productive self expression and civic participation and learn something about the diversity of their communities. For educators seeking effective ways to promote teen volunteering, one lesson is clear in the IS data: Ask them. Roughly half, 51.3 percent, of teens reported having been asked to volunteer. $^{76}$ Of those, a whopping 93.4 percent did indeed volunteer. ${ }^{77}$ Among teens not personally asked to volunteer, only 23.5 volunteered. ${ }^{78}$ While some of this difference is undoubtedly due to selection bias-people ask those teens who are likely to agree to volunteer-the large number of teens not asked to volunteer and the dramatic difference in volunteer rates suggest that proposing

68. See HodGKINSON \& WeITZMAN, supra note 1 , at 2.

69. It is worth noting that the Independent Sector's questions eliciting information on volunteering were the same for their surveys of teenagers and adults; therefore, the higher rates of involvement for teenagers is not an artifact of more detailed questioning.

70. See Nolin ET AL. supra note 64, at 4.

71. See id. at 6.

72. See HodgKinson \& WeItZMan, supra note 62, at 1-16, tbl.1.6.

73. See id.

74. See id. at 2.

75. See id. at $1-15$.

76. See id. at 2-45, tbl.2.10.

77. See id.

78. See id. 
volunteer activities to teenagers can be a remarkably effective way to promote volunteering.

There are at least two reasons why asking a teen to volunteer can be expected to increase volunteering. First, it conveys confidence in the teen's ability to make a good volunteer. Second, it makes teens aware of specific opportunities for volunteering. Both can be accomplished by building community service into school curricula, and having school personnel invite students individually to participate. Both surveys find that the majority of school-aged teenagers attend schools that encourage community service. ${ }^{79}$ In the IS data, fifty-nine percent report that their school encourages community service. ${ }^{80}$ One student in six reports attending a school that requires community service for graduation, double the proportion reporting such requirements in the first IS survey of teens, conducted only four years earlier. ${ }^{81}$

The NHES survey also finds that most school children in grades six through twelve attend schools that arrange or require opportunities for community service. $^{82}$ Of the nation's 25.7 million schoolchildren in grades six through twelve, the report estimates that 4.2 million attend schools at which community service is both arranged and required. ${ }^{83}$ Another 0.4 million attend schools where there is a requirement, but the school does not arrange the service; and 17.4 million attend schools that arrange but do not require community service. ${ }^{84}$ Only 3.7 million attend schools that neither arrange nor require community service. $^{85}$ In other words, out of every six schoolchildren in grades six through twelve, one attends a school that arranges and requires community service; four attend a school that arranges community service opportunities but does not require them; and one attends a school that does not provide opportunities for community service. A very few students, about 1.5 percent of the total, attend schools that require community service but do not arrange it.

The survey's results suggest that a school policy of arranging community service options has almost as large an effect as both arranging and requiring community service. Of children in schools that arrange but do not require community service, fifty-two percent had, at the time of the interview, performed some community service during the school year. ${ }^{86}$ This is only slightly less than the fifty-six percent of students estimated to have performed community service in schools that both arrange and require it. ${ }^{87}$ These percentages are large compared with the participation rate for children whose schools neither

79. See id. at 3-58, fig.3.1; NOLIN ET AL. supra note 64, at 16.

80. See HodgKinson \& WeItZMAn, supra note 62, at 3-58, fig.3.1.

81. See id. at tbl.3.3.

82. See NOLIN ET AL. supra note 64, at 16 .

83. See id. at 17.

84. See id.

85. See id.

86. See id.

87. See id. 
arrange nor require community service, of whom thirty percent participate. ${ }^{88}$ At schools where service is required but not arranged, only nineteen percent of students had performed service by the time of the interview. ${ }^{89}$

The type of school students attend also affected the likelihood that they would volunteer. Participation rates were higher at private schools than at public ones. ${ }^{90}$ Among private schools, the volunteer rate was higher at churchrelated schools, sixty-nine percent, than at others, forty-seven percent. ${ }^{91}$ Participation rates were slightly higher, fifty percent versus forty-seven percent, among children exercising choice among public schools. ${ }^{92}$

Besides the type of school and the schools' orientation toward community service, individual, family, and community factors also affected a child's likelihood of volunteering. Students in the eleventh or twelfth grades, with high grades in courses, and who were involved in many student activities had higher than average participation rates. ${ }^{93}$ Girls participated more than boys; students of Hispanic or African-American background participated somewhat less than whites, as did students for whom English was not the language they spoke most at home. ${ }^{94}$ Students who were active in other school activities, particularly in student government, were more likely to be involved in community service; 81.7 percent of students who have been active in student government reported having volunteered in the past twelve months. ${ }^{95}$

The likelihood of volunteering rose with household income, parents' educational attainment, the presence of a second parent or guardian in the home, and the presence in the home of an adult who performs community service. ${ }^{96}$ Students were more likely to participate in community service regularly, rather than just once or twice, if there was an adult in the household who performed community service or if a parent held a professional degree. ${ }^{97}$ Participation rates were also higher in communities with greater economic resources, where poverty rates were lower and rates of home ownership were higher. ${ }^{98}$

Multivariate analysis reveals that some of these correlations may not reflect direct effects of school, individual, family, and community variables on participation in community service. The two variables measuring a community's wealth-poverty and home ownership rates-have no statistical significance in a multivariate logistic regression. ${ }^{99}$ Similarly, household resources as measured

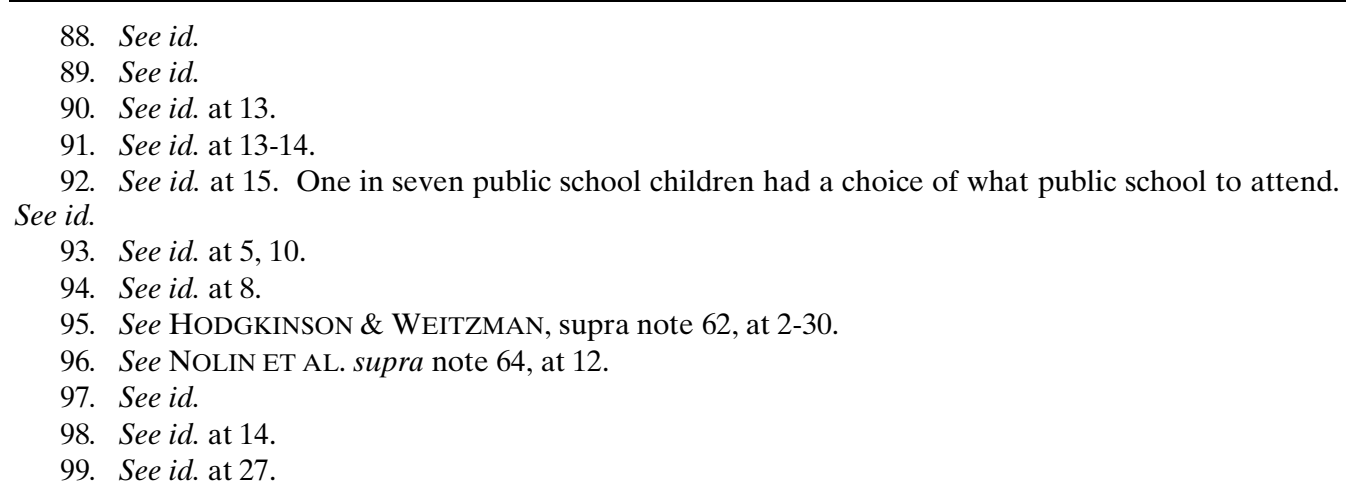


by the number of parents and household income do not matter. ${ }^{100}$ Neither does the race of the student, nor attendance at a private school if that school is not church-related. ${ }^{101}$

Most important for policy considerations, attendance at a school that arranged opportunities for community service had a large and positive impact on the likelihood of student participation. In the 1996 IS survey of teens ages twelve to seventeen, when questioned about who asked them to volunteer for the activity with which they were involved, "a teacher, school, or other school personnel" was the most common response. ${ }^{102}$ Neither requiring service nor the combination of requiring and arranging service had independent statistical power. Combining this information with the results of the IS survey suggests that arranging volunteering opportunities for students and inviting them to participate seem to constitute a recipe for success.

Given the large scale on which America's schools are undertaking community service initiatives, an assessment of these programs should be undertaken. There are reasons to expect that the payoffs while real may be delayed, perhaps for decades. Evidence from panel data suggests that persons go through a lifecycle pattern of voluntarism. ${ }^{103}$ Self-centered forms of engagement dominate early adulthood, peaking at age thirty-five. Once an individual is established in the labor force, and in many cases becomes a parent, community-centered involvement takes on greater importance. When the time comes for community involvement, the effects of early participation may well be seen.

III

\section{Do VolunteER EXPERIENCES DURING YOUTH Plant SEEDS FOR FUTURE VOLUNTEERING?}

Community service requirements are becoming prevalent in American schools, and people who volunteer during their youth are much more likely to volunteer as adults. ${ }^{104}$ If this relationship between youth and adult volunteering is a causal one, then school-based programs of required community service may serve to breed future volunteers. Causal views stress learning: Community service can give young people a sense of the volunteer opportunities that are available, the knowledge that they can accomplish worthwhile tasks, and a taste of the psychic rewards that flow from helping others. On the other hand, selec-

100. See id.

101. These conclusions are based on the author's own calculations using the 1996 Giving and Volunteering survey data.

102. See HodgKinson \& Weitzman, supra note 62 , at 4 .

103. Evidence for this view comes from work by Thomas Janoski and John Wilson, based on panel data collected by the Survey Research Center of the University of Michigan. Using three waves of the Youth-Parent Socialization Panel Study of children and their parents, beginning when the children are 18 and ending when they are 35, Janoski and Wilson find that a student's activities during high school significantly affect their level of community-oriented participation 17 years later. See Thomas Janoski \& John Wilson, Pathways to Voluntarism: Family Socialization and Status Transmission Models, Soc. FORCES, Sept. 1995, 271, 279-83.

104. See infra Table 3 and related discussion. 
tion-bias models propose that some people may simply be predisposed to volunteer, regardless of age, by their attitudes and by access to resources that afford them the option of volunteering. If the correlation between youth and adult volunteering is due entirely to pre-determined behaviors, attitudes, and options, then compulsory community service will do little to create future volunteers. Any speculation about the effect of requiring community service on the future behavior of today's students must engage the question of the extent to which the link between youth and adult volunteering is a causal one.

TABLE 3

Adult Volunteering, By AtTitudes, ResourCes, AND YOUTH VOLUNTEERING

\begin{tabular}{|c|c|c|c|}
\hline \multirow[t]{2}{*}{ Among Adults Characterized By } & \multicolumn{3}{|c|}{ Percent Volunteering } \\
\hline & Overall & $\begin{array}{l}\text { Volunteered } \\
\text { as youth }\end{array}$ & $\begin{array}{l}\text { Did not } \\
\text { volunteer } \\
\text { as youth }\end{array}$ \\
\hline Good attitudes (n=1067) & 65 & 74 & 52 \\
\hline Income $>\$ 25,000(n=1693)$ & 55 & 69 & 36 \\
\hline Bad attitudes $(\mathrm{n}=123)$ & 11 & 12 & 10 \\
\hline Income $<\$ 25,000(\mathrm{n}=895)$ & 33 & 50 & 21 \\
\hline Single parents $(\mathrm{n}=174)$ & 40 & 59 & 28 \\
\hline $\begin{array}{l}\text { Good attitudes } \\
\text { and adequate income }(n=735)\end{array}$ & 72 & 78 & 60 \\
\hline $\begin{array}{l}\text { Good attitudes } \\
\text { but single parent }(\mathrm{n}=66)\end{array}$ & 59 & 68 & 51 \\
\hline $\begin{array}{l}\text { Good attitudes } \\
\text { but low income }(\mathrm{n}=299)\end{array}$ & 50 & 61 & 39 \\
\hline $\begin{array}{l}\text { Bad attitudes } \\
\text { but adequate income }(n=66)\end{array}$ & 14 & 14 & 13 \\
\hline $\begin{array}{l}\text { Bad attitudes } \\
\text { and low income }(n=56)\end{array}$ & 7 & 8 & 7 \\
\hline Entire sample $(\mathrm{n}=2686)$ & 47 & 63 & 30 \\
\hline
\end{tabular}

Source: These data are based on the author's own calculations using the 1996 Giving and Volunteering survey data.

Note: Persons with good attitudes strongly agree or mostly agree with the statement "It is in my power to do things that improve the welfare of others," and state as a major motivation either "helping individuals meet their material needs" or "enhancing the moral basis of society." Persons with bad attitudes disagree with the first statement and report that the second and third statements' objectives provide no motivation. Persons with low (adequate) income have household income of less than (no less than) $\$ 25,000$. 
The data presented in Table 3 illustrate the independent importance of youth volunteering, access to resources, and personal attitudes to rates of volunteering among adults. The attitude variable, described below, is constructed from data available in the IS survey and is designed to reflect both a person's desire to contribute to society and her confidence that she can contribute.

Research on motivation to volunteer is consistent with this approach. Cnaan and Robin Goldberg-Glen review twenty-seven studies of individuals' motivation to volunteer. ${ }^{105}$ They extract from the literature twenty-eight commonly cited motives and ask a sample of 258 "habitual volunteers" (defined as providing at least one hour of direct service at least once every other week over a six-month period) and 104 non-volunteers to rate the personal importance of each. ${ }^{106}$ Some of the motives are altruistic: Volunteers agree with the statements that volunteering "[c]reates a better society," and if they did not volunteer "[t]here would be no one to carry out this volunteer work." 107 Others were egoistic: Volunteers noted motives such as "[b]roadening horizons" and the "[o]pportunity to vary activities." 108 There were material motives—“[g]aining some practical experience toward paid employment"-and social motives-volunteering provides an "[o]pportunity for relationships."

Respondents ranked the importance to their own behavior of each possible motivation on a scale from one (not important) to five (very important). Two motives earned average rankings above 4.0: "[o]pportunity to do something worthwhile" and "[m]akes one feel better about oneself." ${ }^{110}$ Both of these demonstrate an egoistic pleasure found in performing actions that benefit others.

This information suggests two key attitudes for volunteers: First, one's actions have some impact, and, second, one can be motivated by concern for others. To measure a respondent's sense of empowerment, I use the IS data to look at the response to a question asking whether the respondent agrees or disagrees with the statement "It is in my power to do things that improve the welfare of others." ${ }^{111}$ If the person answered that he or she strongly agrees or mostly agrees, he or she was considered to have an attitude of empowerment conducive to volunteering. The respondent's concern for the welfare of others is measured by the responses to two questions concerning motivations to give money or to volunteer. If a person listed as a "major motivation" either "helping individuals meet their material needs" or "enhancing the moral basis of society," the respondent was considered to be concerned with others' well-being, material or spiritual. As described earlier in this article, each of these attitudes individually correlates significantly with the propensity to volunteer. These two

105. See Ram A. Cnaan \& Robin S. Goldberg-Glen, Measuring Motivation to Volunteer in Human Services, J. APP. BEHAV. SCI., Sept. 1991, at 269, 275.

106. See id. at 277-78.

107. Id. at 279 .

108. Id.

109. Id.

110. Id.

111. See supra Table 3. 
avenues of concern, material and moral, are positively correlated with each other but represent distinct phenomena; the correlation coefficient (between dummy variables equaling one when there is major concern and zero when there is no concern) is about one half (.507). ${ }^{112}$

A respondent who was both empowered and concerned was considered to have attitudes conducive to volunteering. These are referred to as "good attitudes." A respondent who was neither empowered nor concerned is classified as having "bad attitudes." Of the 2,686 respondents for whom information was available, 1,067 possessed the "good" combination of attitudes-empowerment plus at least one of the two forms of concern-while 123 reported themselves to be both disempowered and unconcerned.

Even with the best outlook on life, limited resources may limit people's ability to volunteer. Two constraints are considered-low income and single parenthood. A person was coded as low income if his or her household income was less than $\$ 25,000$; sensitivity analysis showed that changing the limit to $\$ 20,000$ or $\$ 30,000$ did not substantially change the results. A person was taken to be a single parent if he or she was a single head of household, was neither married nor living with a partner, and lived with at least one child under the age of eighteen.

As shown in the bottom row of Table 3, of the 2,686 survey observations containing the information required for this analysis, forty-seven percent volunteered. The proportion of volunteering among those who reported youth volunteer experiences was more than twice that of non-youth-volunteers, sixtythree percent compared to thirty percent.

Attitudes and income also make significant differences in the proportions of adults volunteering. The effect of controlling for the attitudinal variable is particularly striking. Among people possessing a good attitude, that is, a sense of empowerment and concern for others, sixty-five percent volunteered. Among people with a bad attitude, that is, neither a sense of being able to make a difference nor any motivation to improve others' material or moral well-being, only eleven percent volunteered. People in households with higher incomes were more likely to volunteer-fifty-five percent volunteered in the subsample with incomes of $\$ 25,000$ or more, in contrast to thirty-three percent of those with incomes below $\$ 25,000$. Single parenthood reduces volunteering to a rate of forty percent compared to forty-eight percent among the rest of the population.

The additional importance of youth volunteering is large in the subsamples in which people face resource constraints. Among single parents, for example, only twenty-eight percent volunteer as adults if they did not volunteer as youths, in contrast to fifty-nine percent volunteering among those who volunteered when young. For people in households with incomes below $\$ 25,000$, the volunteer rate among those who did not volunteer as youths was twenty-one

112. These conclusions are based on the author's own calculations using the 1996 Giving and Volunteering survey data. 
percent, in contrast to a fifty-percent volunteer rate among former youth volunteers. For people whose incomes were above $\$ 25,000$, youth volunteering made the greatest percentage point difference in volunteer rates. Without a youth volunteer experience, thirty-six percent of this group volunteered-thirty-three percentage points less than the sixty-nine percent who volunteered as adults after having volunteered as youths.

Youth volunteering makes little difference among adults who possess neither a sense of empowerment nor concern for others. Only eleven percent of the bad attitude group volunteered, and those who had volunteered during youth were only slightly more likely to volunteer than the others-twelve percent versus ten percent. Even with adequate incomes and youth volunteer experience, the bad attitude group has only fourteen percent of its members volunteering. It may be that youth volunteering enlightens many people who enter the experience with bad attitudes and come away empowered and engaged with others. For adults who feel disempowered and unconcerned, youth volunteering, having failed to dislodge these perceptions, had little to offer. The youthvolunteer experience may have provided information about volunteering opportunities, but this information is not useful to people who neither feel that they would be effective volunteers nor show concern for the possible outcomes of such volunteering.

The lesson to be learned from this analysis is that, except for the bad attitude group, the experience of volunteering during youth appears to make a substantial contribution toward spurring people to volunteer as adults. The relationship between youth and adult volunteering is not simply the side effect of some other force, such as attitudes, organizational engagement, or relative freedom from resource constraints, that encourages volunteering across the lifecycle.

At the other end of the lifecycle, older people have accumulated decades of experience and, with their children raised and retirement an option, many have the time to take on new activities. Will they volunteer?

IV

\section{VOLUNTEERING AMONG OLDER ADULTS}

In thinking about adulthood, we often parse it into two pieces, working years and retirement years. When working members of a family retire, the family time budget suddenly may be less tightly stretched, and it is natural for economists to ask how time spent volunteering might respond to this reduction in competing demands for time. Sociologists might note that retirement removes persons from networks of contacts and from what may be an important role in their life, and they might ask how these changes affect people's desire to volunteer. Finally, retirement has historically been linked to declining health; therefore, health status can be expected to be a more important predictor of volunteering among the population over age sixty-five. 
In the 1996 IS survey, older adults, with forty-one percent volunteering, were somewhat less likely to volunteer than younger adults. ${ }^{113}$ The National Survey of Self-Care and Aging ("NSSCA"), a larger survey of older adults conducted in 1990-91, found low levels of volunteering among the aging. ${ }^{14}$ This survey interviewed a stratified sample of 3,485 community-dwelling Medicare beneficiaries living in the contiguous forty-eight states. ${ }^{115}$ The survey asked, "During the last 12 months, did you periodically do volunteer work?" on answers to this question, it is estimated that 19.7 percent of older community-dwelling adults volunteer. ${ }^{117}$ This estimate is lower than the IS data report, and several explanations may contribute to the difference. First, because the NSSCA asked detailed information elsewhere about kinds of informal helping, ${ }^{118}$ volunteer work was likely to be interpreted as formal volunteering only. Second, the lack of prompting about kinds of volunteering may have led to less complete recall in the NSSCA. Finally, the NSSCA asked about periodic volunteering, ${ }^{119}$ which might be expected to discourage affirmative answers from persons whose volunteering was limited and performed at irregular intervals. In short, it is reasonable to conjecture that much of the shortfall in enumerated volunteering in the NSSCA comes from setting the bar a little higher in determining who counts as a volunteer.

As is true among younger adults, being busy exposes older adults to opportunities to volunteer, and this proves to be more important than the higher opportunity cost of time in determining who volunteers. Persons over age sixtyfive are more likely to volunteer if they are married and if they are employed, independent of age and health status. ${ }^{120}$ Among the admittedly small number of persons (sixty) in the 1996 IS data aged sixty-five and over who were working for money, fifty percent volunteered, compared to forty percent of those who were not working for money. ${ }^{121}$

Being less busy, however, may be part of the reason why those older adults who do volunteer, volunteer more. Older volunteers gave slightly more time, on average, than did their younger counterparts, giving an average of 18.2 hours each month, about half an hour more than the 17.6 monthly hours put in on average by younger adult volunteers. ${ }^{122}$ For organizations thinking about targeting

113. These conclusions are based on the author's own calculations using the 1996 Giving and Volunteering survey data.

114. See Jean E. Kincade et al., Older Adults as a Community Resource: Results From the National Survey of Self-Care and Aging, 36 GERONTOLOGIST 474, 477 (1996).

115. See id.

116. See id. at $476-77$.

117. See id. at 477.

118. See id.

119. See id. at 476-77.

120. See Susan M. Chambre, Volunteerism by Elders: Past Trends and Future Prospects, 33 GERONTOLOGIST 221, 226 (1993).

121. These conclusions are based on the author's own calculations using the 1996 Giving and Volunteering survey data.

122. These conclusions are based on the author's own calculations using the 1996 Giving and Volunteering survey data. 
older adults for volunteer recruitment, it is worth noting that when attention is limited to formal volunteering, the gap widens, with older volunteers giving one and one-half hours more time each month. ${ }^{123}$

Jean Kincade et al. use the NSSCA data to explain patterns of volunteering among older adults. ${ }^{124}$ Using data weighted to be nationally representative and multivariate techniques, they examine the impact on the likelihood of volunteering of several potentially important variables. Age is captured by dummy variables, with categories sixty-five to seventy-four years, seventy-five to eightyfour years, and eighty-five years and up. ${ }^{125}$ Educational dummies represent primary grades, some high school, high school or trade school diploma, and at least some college. ${ }^{126}$ There are five income levels, from below the poverty line to 400 percent or more of the poverty line, and five categories for self-evaluated health status, from excellent to poor. ${ }^{127}$ Also controlled for are sex, marital status, African-American heritage, rural versus urban residence, and whether the person lives alone. ${ }^{128}$

One key result of the analysis is that once health status has been controlled for, the retirement years are not marked by a steady decline in volunteering. Persons aged seventy-five to eighty-four were not statistically significantly less likely to volunteer than persons aged sixty-five to seventy-four, and the point estimate of their relative likeliness to volunteer, 0.96 , was very close to one. ${ }^{129}$ Persons over age eighty-five are significantly less likely to volunteer than the group aged sixty-five to seventy-four. ${ }^{130}$

Health status has a powerful effect on volunteering. Persons in very good or excellent health are more than eight times as likely to volunteer as persons whose health is poor. Married and widowed persons are more likely to volunteer than never-married persons. The likelihood of volunteering rises dramatically with education, and less dramatically with income.

Chambre points out that demographic changes hold great potential for increased volunteering in this age group. ${ }^{131}$ Levels of good health and educational attainment among older Americans are rising quickly, ${ }^{132}$ suggesting that even without any policy intervention, volunteering among older adults is likely to increase in the coming decades.

123. These conclusions are based on the author's own calculations using the 1996 Giving and Volunteering survey data.

124. See Kincade et al., supra note 114 , at 478.

125. See id.

126. See id.

127. See id.

128. See id.

129. These conclusions are based on the author's own calculations using the 1996 Giving and Volunteering survey data.

130. These conclusions are based on the author's own calculations using the 1996 Giving and Volunteering survey data.

131. See Chambre, supra note 120 , at 223-24.

132. See id. 


\section{$\mathrm{V}$ \\ VOLUNTEERING AND THE NATIONAL INTEREST}

There are two strands of dialogue relating volunteering to the national interest. As discussed in the context of the AmeriCorps programs, one stresses the service-delivery function volunteers can fill, as lines of government responsibility for human service provision are redrawn. A second major public dialogue links forms of social engagement, such as volunteering, to levels of civic engagement and the functioning of civil society.

The much-cited work of political scientist Robert Putnam highlights group membership as an indicator of social engagement that fosters trust and civic participation among citizens. ${ }^{133}$ Volunteering can be argued to serve the same functions, and the 1996 IS Giving and Volunteering survey data include the questions on trust and membership that are present in the General Social Survey from which Putnam draws these data. The IS data, containing information on both membership and volunteering, provide an excellent opportunity to determine whether volunteering, like joining, is associated with attitudes conducive to civil society, such as trust, as emphasized by Putnam, and also compassion, a variable contained in the IS data. The IS data allow extensions of this analysis to links between volunteering and additional measures of civic engagement, such as confidence in government and propensity to vote. ${ }^{134}$

Looking at any one form of socialization, such as participation in social groups, can at times confound the effects of related forms of socialization not under study. For example, if married people learn to trust and married people tend to join groups, then joining will be related to trusting, whether or not there is a causal relationship between joining and trusting. Table 4 shows the results of logistic regressions relating the likelihood that an individual agrees that "most people can be trusted" to six possible attitude-forming experiences. These experiences include whether the individual belongs to a group other than a religious congregation, membership in a church or synagogue, and whether or not the individual is working, has completed a four-year college degree, has volunteered in the past twelve months, and is living with a spouse or partner. ${ }^{135}$

These regressions measure the direct effect of the independent variables on levels of trust and compassion. They maintain the working hypothesis that causality flows from experience to attitudes, for example, that marriage builds trust rather than that only trusting people enter into marriage. This observation is almost certainly an oversimplification of a two-way cycle of reinforcement in

133. See, e.g., Robert D. Putnam, The Strange Disappearance of Civic America, AM. ProsPECT, Winter 1996, at 34, 48.

134. Portions of the text of this section have been taken from an unpublished manuscript and developed further. See Eleanor Brown \& June Sager Speakman, Voluntarism and Political Activity: Does the Lone Bowler Volunteer? (Nov. 1997) (unpublished manuscript on file with author).

135. Because of retirement, widowhood, and lower levels of college completion in early generations, the analysis also controls for age. 
which trust-building experience leads to trust that leads to further social as well as civic engagement.

TABLE 4

LOGISTIC REGRESSIONS OF TRUST AND COMPASSION ON MEASURES OF ENGAGEMENT

\begin{tabular}{|c|c|c|c|c|}
\hline & \multicolumn{2}{|c|}{ Trust } & \multicolumn{2}{|c|}{ Compassion } \\
\hline & (1) & (2) & (3) & (4) \\
\hline Intercept & $\begin{array}{l}-1.743 * * * \\
(0.000)\end{array}$ & $\begin{array}{l}-1.732 * * * \\
(0.000)\end{array}$ & $\begin{array}{l}-0.535^{* * *} \\
(0.002)\end{array}$ & $\begin{array}{l}-0.538 * * * \\
(0.001)\end{array}$ \\
\hline JOINSEC & $\begin{array}{c}0.137 \\
(0.176)\end{array}$ & & $\begin{array}{l}-0.148 \\
(0.123)\end{array}$ & \\
\hline JOINR & $\begin{array}{c}0.139 \\
(0.144)\end{array}$ & & $\begin{array}{l}0.342 * * * \\
(0.000)\end{array}$ & \\
\hline ACTIVSEC & & $\begin{array}{c}0.206^{*} \\
(0.061)\end{array}$ & & $\begin{array}{l}-0.146 \\
(0.163)\end{array}$ \\
\hline ACTIVR & & $\begin{array}{c}0.116 \\
(0.215)\end{array}$ & & $\begin{array}{l}0.355^{* * * *} \\
(0.000)\end{array}$ \\
\hline VOL & $\begin{array}{l}0.518^{* * * *} \\
(0.000)\end{array}$ & $\begin{array}{l}0.497^{* * * *} \\
(0.000)\end{array}$ & $\begin{array}{l}0.883 * * * \\
(0.000)\end{array}$ & $\begin{array}{l}0.853^{* * * *} \\
(0.000)\end{array}$ \\
\hline EDCOLL & $\begin{array}{l}0.836^{* * * *} \\
(0.000)\end{array}$ & $\begin{array}{l}0.843^{* * * *} \\
(0.000)\end{array}$ & $\begin{array}{l}-0.241 * * \\
(0.017)\end{array}$ & $\begin{array}{l}-0.227 * * \\
(0.023)\end{array}$ \\
\hline MAR & $\begin{array}{l}0.192 * * \\
(0.050)\end{array}$ & $\begin{array}{c}0.191 * \\
(0.051)\end{array}$ & $\begin{array}{l}-0.007 \\
(0.936)\end{array}$ & $\begin{array}{l}-0.025 \\
(0.780)\end{array}$ \\
\hline WORK & $\begin{array}{l}0.246^{* *} \\
(0.018)\end{array}$ & $\begin{array}{l}0.244 * * \\
(0.018)\end{array}$ & $\begin{array}{c}-0.168^{*} \\
(0.078)\end{array}$ & $\begin{array}{l}-0.175^{*} \\
(0.064)\end{array}$ \\
\hline AGE & $\begin{array}{l}0.008 * * * \\
(0.004)\end{array}$ & $\begin{array}{l}0.009 * * * \\
(0.002)\end{array}$ & $\begin{array}{c}0.001 \\
(0.647)\end{array}$ & $\begin{array}{c}0.001 \\
(0.568)\end{array}$ \\
\hline number of observations & 2252 & 2278 & 2446 & 2476 \\
\hline
\end{tabular}

Source: These data are based on the author's own calculations using the 1996 Giving and Volunteering survey data.

Note: The numbers in parentheses beneath the coefficient estimates are the probability of observing an estimated coefficient at least this far from zero in a chi-square distribution in which the true coe fficient is zero. That is, they are the probability levels at which one may have confidence that the effect of the variable is different from zero.

*** significant at the .01 level

** $\quad$ significant at the .05 level

* $\quad$ significant at the 0.10 level

As shown in Table 4, individuals are found to be statistically significantly more likely, at a .05 level of significance, to be trusting if they are volunteers, 
have a college degree, are working, or are living with a spouse or other partner. Trusting also increases with age. Membership in a church or synagogue and membership in a noncongregational organization did not have statistically significant impacts on trust, when other socializing experiences were controlled for. Replacing the membership variables with measures of membership involving at least monthly participation does not increase the significance of the religious membership variable, but it raises the statistical significance of the secular joining variable, which would be viewed as significant at the 10 level.

Persons were considered to be compassionate if they responded that feeling compassion toward people in need was a major personal source of motivation. Only three of the variables have clear effects on compassion. Both membership in a religious congregation and volunteering are strongly associated with the likelihood of a person reporting that compassion is a very important motivating factor. Religious belonging and volunteering are significant at the .0001 level. The other significant variable is college education. Controlling for other factors, individuals with a college degree were significantly less likely to report themselves as motivated by compassion. A respondent's labor market status had a marginally significant impact on compassion, with employed respondents less compassionate at a .10 level of significance. Membership in a noncongregational group had no significant impact on compassion, whether measured as belonging to a group or being active in a group on at least a monthly basis. Of all the forms of social interaction considered, from marriage to work to belonging to groups, the only one significantly related to elevated levels of both trust and compassion was volunteering.

VI

\section{CONCLUSION}

Volunteering is a pervasive and growing phenomenon in the United States, of significance in both the numbers of persons who give their time and in the value of what their time can accomplish. The Independent Sector has recently released some key findings from its 1999 Giving and Volunteering survey. This newest survey suggests that the proportion of American adults volunteering has risen to fifty-six percent. ${ }^{136}$ This estimate is up seven percentage points from IS's 1996 estimate, an increase that vaults the proportion of adults civicly engaged through volunteering past the proportion who voted in the most recent presidential election. Using prevailing labor compensation rates to value the estimated amount of time given in the twelve months before the survey, this volunteered time is worth $\$ 255$ billion $^{137}$; for perspective, this amount surpasses the gross domestic product of Sweden. As American schoolchildren are increasingly exposed to community service, and as successive cohorts of Americans

136. See Independent Sector, Giving and Volunteering in the U.S. (visited Apr. 22, 2000) <http:// www.indepsec.org/media/GandVsummary_1999.html>.

137. See id. 
enjoy higher levels of health and educational attainment, the upward trend in volunteering is likely to continue.

As valuable a resource as volunteering can be, there are limits to the extent to which government can expect volunteers to address its policy concerns. The 1999 IS data suggest that at least half of the volunteering population is only marginally involved, participating in one-shot events or in conjunction with particular holidays. More committed volunteers can make sustained contributions to various endeavors, some of which serve ends pursued by government, but the area of activity that garners the most volunteer time is religion. Government can direct volunteer effort through the use of full-time stipended volunteers, such as those supported through AmeriCorps, but such direct government programs are small in the landscape of volunteering. Most volunteering goes to church and family-related activities rather than farther-flung civic enterprise. Government enthusiasm for volunteerism should not rest on the hope of shifting responsibilities from government to voluntary action. Rather, volunteering should be respected for the substantial and varied contributions volunteers make to causes chosen not through the political process, but directly by citizenvolunteers themselves. 